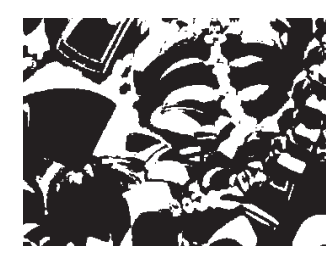

\title{
EFFECTS OF GROUP DISCUSSION ATTACHMENT STYLES AND FACILITATION ON THE QUALITY OF DELIBERATION
}

Metka KUHAR

Faculty of Social Sciences, Ljubliana

Katja JEZNIK

Faculty of Arts, Ljubliana

UDK: 373.3.091.5(497.4)

Izvorni znanstveni rad

Primlieno: 18. 2. 2017.

The work was supported by the Slovenian Research Agency under Grant No. L5-5547.

In this paper, we analyse the effects of group discussion attachment styles and their influence in interactions involving facilitation on the quality of the discussion process (according to deliberative prerequisites, such as equal participation, argumentation and respect). We conducted 26 deliberative discussions with 226 teachers from 13 primary schools on the topic of school discipline measures. The discussions, each including 7-12 participants, lasted 90 minutes; half of them were professionally facilitated in line with the deliberative criteria and half of them were non-facilitated. The higher an individual's group discussion attachment anxiety, the lower their self-assessment of the deliberative functioning and assessment of the group's deliberative functioning. Facilitation improved the assessment of individual deliberative functioning in those individuals who scored higher for group discussion attachment anxiety, while facilitated individuals higher on group discussion attachment avoidance assessed group deliberative functioning lower than the non-facilitated ones.

Keywords: deliberation, group discussion, facilitation, attachment styles, school discipline

$\triangle$ Metka Kuhar, University of Liubljana, Faculty of Social Sciences, Kardeljeva ploščad 5, 1000 Ljubliana, Slovenia.

E-mail: metka.kuhar@fdv.uni-li.si 
Deliberation is a concept stemming from political science. It means the cogent and careful consideration of diverse information and attitudes towards an issue that affects different stakeholders and is relevant for societal development (Bächtiger \& Steenbergen, 2004; Steenbergen, Bächtiger, Spörndli, \& Steiner, 2003). The objective of such consideration is to achieve a sufficient level of agreement on a situation and/or further action in the case of taking a decision entailing different options that is, to legitimise decisions and/or actions. Its essence is made up of democratic communication mechanisms: the quality of discussions on a subject concerning several actors (i.e. the deliberativeness of discussion) as well as the inclusion of all relevant actors in the decision-making process. More concretely, the communication aspect of deliberation means encouraging, through communication practice, the consideration of the deliberative principles so that participants listen to each other, reasonably justify their policy positions, show mutual respect and reflect upon and evaluate their interests and needs from the aspect of their generalisability (Bächtiger \& Steenbergen, 2004, p. 1), and thus arrive at a more reasonable and more legitimate decision. The participants can follow these principles more or less subconsciously, consciously or with the facilitator's assistance.

Despite growing research into deliberation, researchers particularly point out the "lack of understanding of the relations between how different combinations of participants, in psychological terms, and different communication processes and subjective group perceptions influence deliberativeness and attitude change in individuals and the group" (Gastil, Black, \& Moscowitz, 2008, p. 3; Kuhar, 2013). This article focuses on the influence of group discussion attachment styles on the quality of deliberation. Attachment theory (Ainsworth, Blehar, Waters, \& Wall, 1978; Cassidy \& Shaver, 2008) is not only the most prominent theory of interpersonal relationships in recent decades but has also proved to be extraordinarily useful in enhancing the understanding of how individuals function differently in a group (Boccato \& Capozza, 2011; Rom \& Mikulincer, 2003; Smith, Murphy, \& Coats, 1999).

\section{Influence of psychological factors on deliberation}

In recent years, in the area of theoretical/empirical analyses of deliberation, the influence of individual and group-dynamic psychological factors on the quality of deliberation has become one of the most relevant issues (Morrel, 2010; Reykowski, 2006; Rosenberg, 2002, 2005). However, so far, it has been relatively poorly researched (Black, Burkhalter, Gastil, \& Stro- 
DRUŠ. ISTRAŽ. ZAGREB GOD. 27 (2018), BR. 2 STR. 281-303

KUHAR, M., JEZNIK, K.: EFFECTS OF GROUP...
mer-Galley, 2010). Deliberation demands that participants are knowledgeable about the subject under discussion and also interested in talking about it. Moreover, the ability of an individual or group to effectively deliberate depends on several psychological factors. These not only include cognitive factors, on which most of the attention has been placed so far (Lupia, 2002; Mannarini, 2011), but also motivational, personality and affectional factors (e.g. Gastil et al., 2008; Lodge \& Taber, 2000; Marcus, Neuman, \& MacKuen, 2000; Neblo, Esterling, Kennedy, \& Laze, 2008).

There exist two approaches for interpreting psychological factors. They can be viewed in functional terms, whereby situational factors mostly impact personality and cognitive functioning - namely, for many people, these characteristics are substantially malleable (Reykowski, 2006). Psychological factors may also be interpreted in dispositional terms, whereby people's comparatively permanent attributes are the source of their psychological functioning. The functional approach is supported by solid empirical and theoretical arguments. Researching the effects of individual (and group) psychological factors on the quality of deliberation together with situational factors, like facilitation, is thus of considerable importance (Reykowski, 2006).

The literature shows that the initial attitudes of participants are significant for processes of deliberation. Yet, beyond the deliberative process research setting, research on the psychological factors that help shape personal ideologies and attitudes is expanding (e.g. Duckitt, 2001, 2006; Jost, 2006; Kahneman \& Tversky, 2000). Deliberation research has shown that the likelihood of changing attitudes is detrimentally influenced by the ideological bias brought by participants (Gastil et al., 2008; Gastil \& Dillard, 1999). The attitudes of conservative and liberal participants typically become more distant from each other during deliberation. For example, the former end up more strongly supporting conservative beliefs and more evidently rejecting liberal ones, and the reverse also applies. Concluding along the same lines, Wojcieszak (2011, 2012) stressed that it is particularly difficult to alter firm attitudes and impact how individuals process messages. Wojcieszak also stated that as a multidimensional construct, attitude strength has a series of components (e.g. intensity, certainty, extremity and importance), each with a varying impact during deliberation. Any rethinking of biases appears to be particularly limited by emotionally-based attitude intensity and extremity (Wojcieszak, 2012).

Regarding the personality of those participating in a deliberation, within-group variance in attitude change has correlated positively with average group scores on self-reported 
DRUŠ. ISTRAŽ. ZAGREB GOD. 27 (2018), BR. 2, STR. $281-303$

KUHAR, M., JEZNIK, K. EFFECTS OF GROUP... measures of deliberation, extraversion and conscientiousness (Gastil et al., 2008, p. 23). Sager and Gastil (2002) showed that groups with higher mean levels of agreeableness reported higher levels of perceived confirming interaction - which was positively correlated with members' perceptions of democratic decision-making.

\section{Attachment styles and their effects on interpersonal functioning}

Attachment theory was founded by Bowlby (1969/1991) towards the end of the 1960s. He found that children reacted to separation from their caregivers with a predictable series of emotional responses: distress (actively seeking proximity and rejecting other people), despair (passivity, sadness) and detachment (actively avoiding closeness). Later, after observing children's reactions to separation from their caregivers, Ainsworth et al. (1978) distinguished between the following attachment styles: secure attachment, avoidant attachment, ambivalent attachment and disoriented attachment. Despite being extremely relevant for individuals' functioning in groups (Mikulincer \& Shaver, 2001; Rom \& Mikulincer, 2003) and for different aspects of attitude formation (Mikulincer, 1997; Mikulincer \& Shaver, 2001; Shaver \& Mikulincer, 2003; Weber \& Federico, 2007), attachment styles in the context of theoretical/ empirical studies of deliberation have not yet been considered.

In recent years, attachment styles have received research attention with regard to groups. Group attachment styles were first postulated by Smith et al. (1999). By considering the most relevant social group among their respondents, they revealed that the group attachment style of individuals appropriately predicted their emotions about the group, the activities and time spent with the group, self-confidence, ways of resolving intragroup conflict as well as the social support they offer and receive. Consistent with the thesis about the generalisation of attachment styles to new interactions and relationships put forward by Bowlby (1991), for small, functional, task-oriented groups, the authors demonstrated that pronounced interpersonal attachment anxiety helps establish group attachment anxiety, whereas pronounced interpersonal attachment avoidance adds to the formation of group attachment avoidance (Smith et al., 1999).

Rom and Mikulincer (2003) further showed that group attachment anxiety is associated with a sense of being vulnerable, unworthy, helpless as a group member, with concern about being accepted by the group, the perception of group interactions as constituting a threat, negative emotional reactions to group interactions and a lower assessment of self-efficacy within the group. Moreover, the assessment of closeness 
DRUŠ. ISTRAŽ. ZAGREB GOD. 27 (2018), BR. 2 STR. 281-303

KUHAR, M., JEZNIK, K.: EFFECTS OF GROUP.. to the group as being unnecessary and the tendency to avoid being dependent on the group are associated with group attachment avoidance. In their study, where more negative than positive emotions were elicited by the group, the views of other group members were more negative, and the need for distance from the group and self-reliance was greater.

Rom and Mikulincer (2003) showed that regarding a person's contribution to the outcomes of the group, anxious attachment is linked with weaker instrumental functioning, and avoidant attachment with weaker socio-emotional functioning. Due to their hyperactivating strategies, individuals who are anxiously attached are more strongly focused on ensuring that group interactions retain a positive emotional tone than on the completion of tasks. As these individuals' main preoccupation is their desire to be accepted, loved and supported by others, they chiefly invest their psychological resources into promoting a setting of support and acceptance among the group members as well as resolving any intragroup conflicts that might jeopardise the group atmosphere. These strategies necessarily take both their resources and attention away from the tasks and/or achievement of group goals (Rom \& Mikulincer, 2003). Those with pronounced avoidant attachment, with their deactivating strategies, seek emotional and social distance from the group, resulting in a weak(er) link to the socio-emotional aspect of interactions. They make a very weak contribution to establishing consensus and closeness among members of the group and often cause open conflicts with other group members in their attempt to distance themselves. They prefer to invest their time and energy in tasks that do not require any emotional engagement within the group (Rom \& Mikulincer, 2003).

\section{Effect of facilitation on deliberation}

Details about what is facilitation, how facilitation is perceived, which roles are performed by facilitators and how they fulfil them in practice are often missing in studies on deliberation (Wright, 2006, p. 551). While there have been a few attempts to classify facilitation styles (Dillard, 2013; Landwehr, 2014) and define tensions inherent to facilitating deliberative discussions (Spada \& Vreeland, 2013; Thompson \& Hoggett, 2001), research into the effects of facilitation is "strangely absent from the literature" (Smith, 2009, p. 198).

So far, the research results from our study have demonstrated the effect of facilitation on the attitude change and deliberative functioning of discussion participants (for more, see Kuhar \& Jeznik, 2017). To sum up the main findings concerning the effect on deliberativeness, teachers participating in 
DRUŠ. ISTRAŽ. ZAGREB GOD. 27 (2018), BR. 2, STR. $281-303$

KUHAR, M., JEZNIK, K. EFFECTS OF GROUP... facilitated deliberative discussions, compared to those in non-facilitated ones, assessed higher their own deliberativeness and that of the group in terms of certain deliberative criteria (these are stated in the description of the measurement instruments). A difference occurred between the facilitated and non-facilitated groups in the participants' deliberative functioning (it was higher in the facilitated subsample), but not in the self-assessment of one's own deliberative functioning.

\title{
AIM OF THE RESEARCH
}

\begin{abstract}
$\longrightarrow$ Our experiment's design was motivated by the acknowledged importance of facilitation in deliberative discussions, the lack of experimental research involving the manipulation of facilitation and, most of all, the lack of understanding of the influence of psychological factors on deliberation, in particular in connection to facilitation. In a real-life context, we tested (a) how group discussion attachment styles influence deliberative functioning and (b) how facilitation influences deliberative functioning in terms of the participants' group attachment styles.

The study was conducted with a sample of subject teachers from 13 primary schools in Slovenia, divided into two categories: those professionally facilitated in line with the deliberative criteria and control groups. Our hypotheses were as follows:

H1: Group discussion attachment styles will influence the assessment of one's own and the group's deliberative functioning.

H2: Facilitated individuals will assess their own and the group's deliberative functioning higher than non-facilitated ones, regardless of the group discussion attachment style.
\end{abstract}

\section{METHODOLOGY}

\section{Participants}

The deliberation experiment was conducted with 226 teachers of the second stage of primary education (grades 6 to 9). We selected 13 schools by taking several criteria into account, to include schools from (a) all 12 Slovenian regions; (b) larger and smaller cities, suburban areas and rural areas; (c) schools of different sizes; and (d) private schools and/or schools applying different education theories. ${ }^{1}$ The sampling method was nonprobability purposive sampling.

After selecting the sample of primary schools, we contacted the principals and invited their schools to participate. Three initially selected schools' principals refused to participate; 
DRUŠ. ISTRAŽ. ZAGREB GOD. 27 (2018), BR. 2 STR. $281-303$

KUHAR, M., JEZNIK, K.: EFFECTS OF GROUP...

\section{Procedures}

thus, we contacted other comparable schools in the same region. The principals obtained the consent of their subject teachers and together we defined the timing of the deliberative discussions. They were held in December 2015 and January 2016.

The final sample of teachers comprised $78.9 \%$ women, which can be expected given the gender structure of the population of primary school teachers, which has recently been found to be $79.4 \%$ female for the second stage of primary education (Statistical Office of the Republic of Slovenia, 2016). The ages of the respondents ranged from 26 to 64 years, with an average of 45.0 (standard deviation $[\mathrm{SD}]=9.76$ ). The share of study participants with a teaching career lasting up to 10 years was $24.8 \%$, those with $10-20$ and $20-30$ years of teaching experience accounted for $30.1 \%$ and $22.1 \%$ of participants, respectively, while $23 \%$ had been teaching for over 30 years. The teachers were working at schools with various numbers of students, ranging from 230 to 837 . Teachers in rural schools accounted for $15.5 \%$ of the sample, teachers from small cities accounted for $25.7 \%$, teachers from medium-sized cities accounted for $28.3 \%$, and teachers from schools in Slovenia's first or second largest cities accounted for $30.5 \%$.

The subsamples (facilitated and non-facilitated) did not differ statistically significantly in terms of age, gender or number of years working as teachers. The facilitated sample included 107 study subjects and the non-facilitated one 109 .

This study adopted a randomised control experimental design, in which, in addition to the experimental intervention, several individual- and group-level control variables were included in the explanatory model. We designed and conducted discussions among teachers on the topic of school discipline measures. These discussions (26 altogether) lasted about 1.5 hours each. Two discussions were conducted simultaneously at each sampled school. The teachers were randomly divided into one of the groups, with 7-12 teachers being assigned to each group. In the individual schools, all teachers in grades 6-9 participated (except for sick or otherwise justifiably absent teachers); therefore, the difference in group numbers is due to school size and absence. ${ }^{2}$

The experimental groups were facilitated by a professional from the Slovenian Association of Facilitators (a Chapter of the International Association of Facilitators) using a highly structured and well-prepared plan. The facilitator guided the teachers' discussion in terms of the content and procedure to meet the deliberative criteria (equal participation in the discussion, argumentation, respect, readiness for change and honesty). Each 
DRUŠ. ISTRAŽ. ZAGREB GOD. 27 (2018), BR. 2, STR. 281-303

KUHAR, M., JEZNIK, K. EFFECTS OF GROUP... facilitated group was invited to seek common ground, carefully weigh each argument and adapt it if necessary. The goal for the control groups was to establish an environment that would closely mirror non-facilitated, real-world discussions; thus, they followed just one criterion - namely, that teachers did not go off-topic, which was ensured by a research team member posing questions. As this criterion is also a prerequisite for other communication intermediation forms and a basic procedural task for other types of intermediaries, such as chairs, moderators and mediators (see Landwehr, 2014), keeping the discussion on topic cannot define even basic, weak or minimal facilitation. In both groups, the discussion concluded with teachers' recommendations for improving discipline measures at the school and national levels. The facilitators did not enforce a consensus, with each group instead being invited to seek common ground (O'Doherty, 2013) - that is, to carefully weigh each recommendation and adapt it if necessary.

\section{Issue for deliberation}

The issue for deliberation - school discipline measures in Slovenian primary schools - is particularly pertinent for teachers because, daily, they need to intervene and ensure appropriate behaviour among students. This topic is highly controversial and subject to public scrutiny, especially in extraordinary cases covered by the media (e.g. publicised examples of school violence). The issue is also important for understanding the educational role of the school. Up until 2009, this area was governed by the Rules on the Rights and Duties, whereas the currently applicable Primary School Act stipulates that since the 2009-2010 school year, every school autonomously defines its own comprehensive system of educational activity and discipline measures, which usually includes preparing three documents at the school level: House Rules, Plan of Moral and Character Education and School Rules. The current regulation imposes on teachers the responsibility of developing an in-depth understanding of their educational activities.

\section{Instruments}

Prior to and after the deliberation, the participants each completed a paper-based questionnaire. The questions related to school discipline measures, which are not the focus of this article, that were repeated before and after the deliberation. Before the deliberation, they answered a set of socio-demographic questions and, after the deliberation, a set of questions about the deliberation and three additional sets of psychological dimensions (attachment styles in intimate relationships, group attachment styles and values). Upon arrival, subjects were as- 
DRUŠ. ISTRAŽ. ZAGREB GOD. 27 (2018), BR. 2 STR. $281-303$

KUHAR, M., JEZNIK, K.: EFFECTS OF GROUP..

(1) TABLE 1

Group discussion attachment styles signed random numbers allowing us to link the questionnaires they completed before the deliberation with those after, and thus also ensure their anonymity. The questionnaires were digitalised using a web survey tool.

\section{Group discussion attachment styles}

We took a step forward from Smith et al. (1999), who designed a measurement instrument for group attachment styles. This is practical for teams or groups that have already achieved a certain level of cohesion. In deliberations - but not only in the context of deliberation - a group might meet only once. In principle, we could use the questionnaire for measuring interpersonal attachment styles, but this instrument contains, relatively speaking, very intimate questions and is thus inappropriate in certain contexts, such as in a discussion on issues of public concern. Based on the available instruments for measuring interpersonal and group attachment styles, we designed an instrument for measuring group anxiety and avoidance attachment in the context of discussion. Group discussion attachment (hereinafter GDA) anxiety and GDA avoidance were each measured with seven indicators. Both were self-report measures. Based on factor analyses of both sets of statements, we created indexes of group discussion attachment styles, with the first comprising six variables and the second, three variables (Table 1).

\footnotetext{
GDA anxiety

I almost always feel as if others are better at expressing their opinion than me. I find it difficult to express my opinion decisively.

If others disagree with me, I feel very uncomfortable.

I usually feel uncomfortable, although I don't really know why. After the discussion, I often bother myself with the fact that my participation wasn't better or good enough.

I am afraid of negative responses that could follow my participation in a discussion.

(Cronbach's Alpha: 0.864)

GDA avoidance I personally don't have any troubles with opening up in front of other people in the group.*

I am comfortable with sharing my feelings with others in the group.*

I am usually enthusiastic about group discussions.*

(Cronbach's Alpha: 0.629)
}

Note: Scales with values $1-5$, where $1=$ totally disagree with the statement and $5=$ totally agree with the statement; to calculate the value of individual indexes we reverse scored the statements marked with *.

\section{Deliberative functioning}

Some experiments have already operationalised deliberative standards for the empirical analysis of speech units. The best known is the Discourse Quality Index (Bächtiger, Shikano, Pedrini, \& Ryser, 2009; Steiner, 2012). We did not encode speech 
DRUŠ. ISTRAŽ. ZAGREB GOD. 27 (2018), BR. 2, STR. $281-303$

KUHAR, M., JEZNIK, K. EFFECTS OF GROUP... units from the deliberations, since we used self-reported perceptions of the discussions' quality for various deliberative functioning characteristics. The subjects expressed their views on their deliberative functioning and the deliberative functioning of the other participants. Our selection of deliberative criteria and indicators for measuring them was based ontheory, although examples of existing, albeit rare, operationalisations were also followed (Fulwider, 2005; Gastil et al., 2008; Halvorsen, 2001; Nabatchi, 2007; Petrič, 2014; Reykowski, 2006).

We intended to measure a wide variety of deliberation qualities that are commonly reported by researchers - equal participation in the discussion, argumentation, analytical approach, readiness for change, honesty and respect - with the last of these being divided into recognition and appraisal respect (Darwall, 1977). In the study, we adopted items from various scales addressing the above-mentioned deliberative criteria (Fulwider, 2005; Gastil et al., 2008; Halvorsen, 2001; Petrič, 2014; Reykowski, 2006; Steenbergen et al., 2003). Some items were originally developed according to the conceptual definitions of the deliberative criteria. The initial item pool was evaluated for face validity and content validity by members of the research team, and item selection was performed so as to arrive at a minimum of three items per deliberative criterion. Each item was measured on a Likert-type scale ranging from $1=$ completely disagree to $5=$ completely agree. Using the obtained data, factor analyses (oblimin rotation) were conducted on the individual dimensions of deliberation quality. After excluding several items, we arrived at scales with good reliabilities (see Appendices 1 and 2).

Based on the factor analyses of both sets of criteria, we created indexes of deliberative functioning from the individual deliberative criteria, one for a person's self-assessment and another for the assessment of the group.

\section{RESULTS}

\section{Descriptive statistics}

As seen in Table 2, the average value for GDA avoidance was $2.64(S D=0.40)$ and for GDA anxiety it was $2.43(S D=0.72)$. The subsamples (facilitated and non-facilitated) did not differ statistically significantly in terms of these dimensions $(p=0.280$ for GDA avoidance and $p=0.168$ for GDA anxiety).

The mean value of a person's self-assessment of deliberative functioning was $4.20(S D=0.43)$. The facilitated groups did not differ statistically significantly from the non-facilitated 
(1) TABLE 2

Comparison of quality of deliberation dimensions among individuals in facilitated vs. non-facilitated groups (t-tests) ones $(p=0.174)$. The mean value of the total index of group deliberative functioning was $3.96(S D=0.45)$. The value of this index was significantly $(p<0.001)$ higher for individuals in the facilitated groups $(M=4.07, S D=0.40)$ as compared to the non-facilitated groups $(M=3.85, S D=0.47)$.

\begin{tabular}{|c|c|c|c|c|c|c|c|}
\hline & \multicolumn{2}{|c|}{$\begin{array}{l}\text { Overall } \\
\text { sample }\end{array}$} & \multicolumn{2}{|c|}{$\begin{array}{r}\text { Facilitated } \\
\text { respondents }\end{array}$} & \multicolumn{2}{|c|}{$\begin{array}{r}\text { Non-facilitated } \\
\text { respondents }\end{array}$} & \multirow[b]{2}{*}{$p$} \\
\hline & M & $S D$ & $M$ & $S D$ & $M$ & $S D$ & \\
\hline GDA avoidance & 2.64 & 0.40 & 2.61 & 0.40 & 2.67 & 0.39 & 0.280 \\
\hline GDA anxiety & 2.43 & 0.72 & 2.37 & 0.77 & 2.50 & 0.65 & 0.168 \\
\hline Individual deliberative functioning & 4.20 & 0.43 & 4.24 & 0.36 & 4.16 & 0.49 & 0.174 \\
\hline Group deliberative functioning & 3.96 & 0.45 & 4.07 & 0.40 & 3.85 & 0.47 & $<0.001$ \\
\hline
\end{tabular}

\section{Correlation analyses}

As seen in Table 3, GDA avoidance was statistically significantly positively correlated with GDA anxiety $(r=0.298, p<$ $0.05)$, and negatively with individual deliberative functioning $(r=-0.254, p<0.001)$ and group deliberative functioning $(r=$ $-0.171, p<0.05)$. The analysis also showed a statistically significant negative correlation between GDA anxiety and individual deliberative functioning $(r=-0.392, p<0.001)$ and group deliberative functioning $(r=-0.286, p<0.001)$. Individual de-

(1) TABLE 3

Correlation analyses among GDA avoidance and anxiety, individual and group deliberative function and facilitation liberative functioning was statistically significantly correlated only with group deliberative functioning $(r=0.782, p<0.001)$ and not with facilitation, whereas group deliberative functioning was statistically significantly correlated with facilitation $(r=0.240, p<0.001)$.

\begin{tabular}{|c|c|c|c|}
\hline & $\begin{array}{c}\text { GDA } \\
\text { avoidance }\end{array}$ & $\begin{array}{l}\text { GDA } \\
\text { anxiety }\end{array}$ & $\begin{array}{l}\text { Deliberative functioning: } \\
\text { individual group }\end{array}$ \\
\hline GDA anxiety & $0.298^{*}$ & & \\
\hline Deliberative functioning: individual & $-0.254^{* *}$ & $-0.392^{* *}$ & \\
\hline Facilitation $\quad$ group & $-0.171^{*}$ & $-0.286^{* *}$ & $\begin{array}{l}0.782^{* *} \\
0.093\end{array}$ \\
\hline
\end{tabular}

Note: ${ }^{*} p<0.001,{ }^{*} p<0.05$

\section{Regression analysis}

After determining the correlations, the above-described bivariate relationships between group discussion attachment styles, facilitation and deliberative functioning were tested further for causation in multiple regression analyses. While running the analyses, we checked for multicollinearity, and there were no such issues. We conducted two separate regression analyses 
DRUŠ. ISTRAŽ. ZAGREB GOD. 27 (2018), BR. 2, STR. 281-303

KUHAR, M., JEZNIK, K.: EFFECTS OF GROUP... with the intention of investigating whether the influence of the independent variables (GDA anxiety and avoidance) on the dependent (deliberative functioning - both assessments) differed in terms of facilitation.

The results of the three-step hierarchical regression analyses, separately for individual deliberative functioning and group deliberative functioning as dependent variables, are displayed in Table 4 . In the first step of analyses, we entered models consisting of gender, teachers' age and school size as control variables. The models were not significant for any of the dependent variables. In the second step, besides control variables from the first step, we added group attachment anxiety and avoidance, as well as facilitation presence as independent variables, to check for main effects on the deliberative functioning assessments. The models were significant both for the individual $(F(3,191)=16.19, p<0.001)$ and for group $(F(3,186)=11.24, p<0.001)$ deliberative functioning. Individual deliberative functioning was positively predicted by gender. Women have higher self-assessment scores of deliberative functioning than men. GDA anxiety was a negative predictor for both of the deliberative functioning indexes, while facilitation proved to be a significant positive predictor only for group deliberative functioning assessment (Table 4).

In the final model, we included the main effects from the previous step of analyses, together with the interaction effects of both attachment variables with facilitation (Table 4). For the individual deliberative functioning, the third model yielded significant improvement compared to the model without interactions $(20.6 \%$ of explained variance, $F(2,189)=3.52, p<0.032)$. Gender remained a significant predictor, as well as GDA anxiety. Although facilitation did not have a significant main effect on the dependent variable, interaction of facilitation and GDA anxiety had a significant explanatory effect on the variations in the individual deliberative functioning. As far as the group deliberative functioning as dependent variable is concerned, the third model explained $15.1 \%$ of variance in total, but it was not significantly better in predicting the values from the model constructed in the second step $(F(2,184)=2.92, p<0.056)$. However, along with GDA anxiety and facilitation as significant predictors, the interaction between avoidance and facilitation had a predictive value $(\beta=0.16, p=0.035)$.

To further explore (significant) interaction effects, line graphs reflecting the relationship between GDA dimensions and deliberative functioning variables were plotted, with separate lines for facilitated and non-facilitated individuals (Figures 1 and 2). Predicted values on deliberative functioning for participants with mean scores for group attachment variables as well as those who scored one standard deviation below and above the mean were calculated and plotted. 


\begin{tabular}{|c|c|c|c|c|c|c|}
\hline \multirow[b]{2}{*}{ Variable } & \multicolumn{3}{|c|}{ Individual DF } & \multicolumn{3}{|c|}{ Group DF } \\
\hline & Step 1 & Step 2 & Step 3 & Step 1 & Step 2 & Step 3 \\
\hline Gender & 0.091 & $0.141^{*}$ & $0.132^{*}$ & 0.001 & 0.043 & 0.037 \\
\hline Age & -0.002 & -0.031 & -0.031 & -0.088 & -0.101 & -0.097 \\
\hline Number of pupils & -0.025 & -0.026 & -0.031 & -0.019 & 0.001 & 0.008 \\
\hline GDA anxiety & & $-0.397^{* *}$ & $-0.365^{*}$ & & $-0.310^{* *}$ & $-0.305^{* *}$ \\
\hline GDA avoidance & & -0.100 & -0.097 & & -0.059 & -0.053 \\
\hline Facilitation & & 0.127 & 0.119 & & $0.243^{* *}$ & $0.246^{* *}$ \\
\hline Facilitation x Anxiety & & & $0.187^{* *}$ & & & 0.147 \\
\hline Facilitation $x$ Avoidance & & & -0.106 & & & $-0.158^{*}$ \\
\hline \multicolumn{7}{|l|}{ Model summary } \\
\hline$R$ & 0.095 & 0.458 & 0.488 & 0.090 & 0.400 & 0.432 \\
\hline Adjusted $R^{2}$ & -0.006 & $0.185^{* *}$ & $0.206^{* *}$ & -0.008 & $0.133^{* *}$ & $0.151^{* *}$ \\
\hline$\Delta R^{2}$ & 0.009 & $0.201^{* *}$ & $0.028^{*}$ & 0.008 & $0.152^{* *}$ & 0.026 \\
\hline
\end{tabular}

Note: ${ }^{* *} p<0.001,{ }^{*} p<0.05$; Gender: $1=$ female, Facilitation: $1=$ facilitated

(1) TABLE 4

Regression analysis results of predicting individual and group deliberative functioning (DF) for facilitated and non-facilitated participants

FIGURE 1

Relationship between GDA anxiety and individual deliberative functioning for facilitated and non-facilitated individuals

FIGURE 2

Relationship between GDA avoidance and group deliberative functioning for facilitated and non-facilitated individuals
Facilitation improved the assessment of individual deliberative functioning (Figure 1) for individuals who scored higher in GDA anxiety.

Concerning the influence of GDA avoidance on deliberative functioning, regression analysis with interaction showed that facilitation improved the assessment of group deliberative functioning most for individuals who scored lower in GDA avoidance (Figure 2).
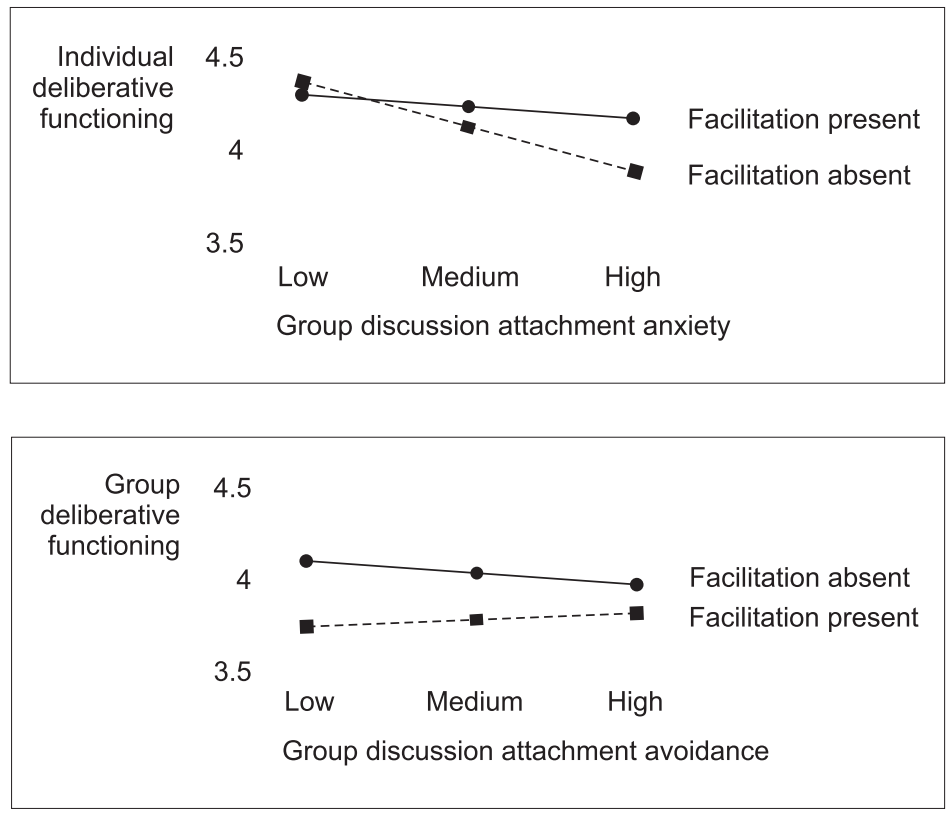
DRUŠ. ISTRAŽ. ZAGREB GOD. 27 (2018), BR. 2, STR. 281-303

KUHAR, M., JEZNIK, K. EFFECTS OF GROUP...

\section{DISCUSSION}

The results partly confirm $\mathrm{H} 1$ - that is, GDA anxiety will influence the assessment of one's own and the group's deliberative functioning. GDA avoidance did not predict any of the two deliberative functioning indexes. The results partly confirm $\mathrm{H} 2$ - that is, facilitated individuals with higher GDA anxiety assessed individual deliberative functioning higher than non-facilitated ones. Furthermore, facilitated individuals with higher GDA avoidance assessed group deliberative functioning lower than non-facilitated ones.

Our study was designed to test the effects of a selected psychological factor (group discussion attachment style) on deliberative functioning (self-assessed) and the impact of their interaction with facilitation on deliberative functioning. Attachment theory has usually been applied in the context of individual relationships, although it has also been shown to be relevant for explaining group relationships (Boccato \& Capozza, 2011; Rom \& Mikulincer, 2003; Smith et al., 1999). The group aspect - closeness to the group, inclusion in the group and belonging - also has an evolutionary value, and our attachment systems are hypothesised to serve these needs too, and through them provide support, care, etc. (Ein-Dor \& Hirschberger, 2016). Similar to interpersonal attachment, anxiety and avoidance are also expected to emerge as underlying dimensions in the case of attachment to groups. Smith et al. (1999) found that group-related anxiety and avoidance were positively correlated with the respective dimension of interpersonal attachment; however, they demonstrated that group attachment is a distinct construct. In this study, we took a step forward from Smith et al. (1999) and designed a measurement instrument for group discussion attachment styles which can be used in deliberations where a group might meet only once. We tested the effect of group discussion attachment styles in interaction with facilitation on deliberative functioning.

In line with our expectations, the regression analysis showed that higher GDA anxiety was reflected in a lower assessment of deliberative functioning, which applied to both self-assessment and assessment of the group. As Smith et al. (1999) showed, individuals who scored high in group anxiety displayed an excessive preoccupation with acceptance by (valued) groups; therefore, they tried to conform to the group prototypes. Rom and Mikulincer (2003) further demonstrated that anxiously group-attached individuals with a negative representation of themselves as group members, together with the perception of threat and the experience of unpleasant emotions and the constant search for approval, primarily pursued 
DRUŠ. ISTRAŽ. ZAGREB GOD. 27 (2018), BR. 2 STR. 281-303

KUHAR, M., JEZNIK, K.: EFFECTS OF GROUP..

\section{Limitations}

socio-emotional goals in group interactions and showed an impaired performance in group tasks. Lower self-assessment can be expected owing to their poorer self-image, excessive preoccupation with matching with the group and efforts to be accepted by others.

The regression analysis did not demonstrate that GDA avoidance would influence (any assessments of) deliberative functioning. Though an avoidant individual, according to theory, does not have any desire for a group activity (Rom \& Mikulincer, 2003; Smith et al., 1999), our participants did not assess their involvement in a longer-lasting group. The questions posed to them asked about the level of comfort of opening up in front of others, etc., but they might have been influenced by the desire to perform well, which was easier in a temporary group setting and the topic did not require emotional opening.

As regards the interaction between group attachment styles and facilitation, the statistically significant predictor of the individual deliberative functioning index was the interaction between facilitation and GDA anxiety. This means that, in non-facilitated individuals, anxiety more negatively influenced the deliberative functioning than in facilitated ones. Based on these results, we can conclude that facilitation improved (the assessment of) the deliberative functioning in individuals scoring higher for GDA anxiety. Individuals of the anxious GDA type felt more comfortable in a facilitated group.

For GDA avoidance, there was an interaction effect with facilitation influencing (the assessment of) group deliberative functioning. Facilitated individuals higher on GDA avoidance assessed group deliberative functioning lower than their non-facilitated counterparts. We can interpret that they would preferably pursue their agenda without participating in a way that was required by facilitation (e.g., empathic attunement to others' perspectives etc.).

Our study had several limitations that may encourage future studies. One pertains to the sample's demographics. Participants had equal levels of education and a similar social status, which may represent an advantage but at the same time deliberative publics usually consist of people with differing socio-economic background.

The sample also included participants from school collectives (pre-existing groups), which may have predisposed participants to group interactions, particularly in the non-facilitated groups. Especially for the purposes of researching the deliberative democracy framework, further experiments with 
DRUŠ. ISTRAŽ. ZAGREB GOD. 27 (2018), BR. 2, STR. 281-303

KUHAR, M., JEZNIK, K. EFFECTS OF GROUP... people who do not know each other and meet only in the context of a deliberation are recommended. Our construct for measuring group discussion attachment cognitions and behaviours is suitable for measuring characteristics in a deliberative context, but not in a permanent group context. Nonetheless, the construct proved to be reliable. We explain this by the fact that teachers are quite independent in their work and most of their tasks are not team tasks.

In addition, in the experimental group that was professionally facilitated, this role was performed only by a single professional facilitator. It would be relevant to introduce variation in the form of several qualified facilitators.

What remains for further investigations is, first, to use a mixed methods approach to analyse the participants' statements. We focused only on the participants' self-assessments of deliberativeness, and GDA anxiety and avoidance measures were self-report measures.

\section{Implications for practice}

Our research clearly demonstrates that facilitation improved the assessment of the group's deliberative functioning in individuals who scored higher for GDA anxiety. On the other hand, it negatively affected (at least the assessment of) group deliberative functioning individuals with higher GDA avoidance. So, on the one hand, facilitating is very important, as we can expect that GDA anxiety was relatively high for about a quarter of the participants, who were otherwise negatively impacted by functioning in groups (in the case of one-time participation in deliberation). On the other hand, for another quarter of the participants (rough estimate) it seems to be significant how the facilitation is performed not to enforce them into more contact, openness, attunement to others than they have a capacity or readiness.

Despite the complexity of how to take care of individuals with differing capacities for group interactions, in terms of educational policies, the importance of structured and conscious facilitation of discussions in accordance with deliberative criteria among teachers was clearly demonstrated. Facilitation practices seem also to be important for school class management, but are inadequately represented in initial teacher education. We do not claim that all teachers should be trained specifically in facilitation skills. What is most significant seems to be that discussions in a classroom or in a teacher's chamber are conducted in accordance with certain communication criteria and raise awareness of the discussion process itself, while considering the psychological characteristics of individuals, such as their (group discussion) attachment style. 
1 We only identified two private schools and another three public schools that applied special pedagogical principles. One was included in the sample (a private school with the Waldorf pedagogy, as this education theory is the most known and established).

2 Since the study was conducted in the winter, some teachers were on sick leave.

\section{APPENDIX 1}

\section{Self-assessment of deliberative functioning}

Equal participation in discussion

Argumentation

Respect from the other participants: recognition

Respect from the other participants: appraisal

Respect toward the other participants

Readiness for change
*Some participants arranged for themselves more space to voice their opinion than me.

*Although my views were elaborate, I did not find proper motivation to participate.

$(M=4.0, S D=0.8$, Cronbach's Alpha $=0.616)$

I was willing to justify everything I said.

My arguments were based on my own experience.

$(M=4.5, S D=0.5$, Cronbach's Alpha $=0.687)$

I had a feeling that others were listening carefully to what I had to say. *Sometimes, I had a feeling that other participants did not even bother to understand what I had to say.

${ }^{*}$ I received some unfriendly responses during the discussion.

*In my opinion, others did not consider enough what I had said.

$(M=4.4, S D=0.6$, Cronbach's Alpha $=0.792)$

I have a feeling that others in the discussion found my comments useful.

Others upgraded the ideas I had expressed earlier.

*I had a feeling that others respected what I had said.

$(M=4.0, S D=0.5$, Cronbach's Alpha $=0.697)$

In my assessment, the other participants were competent speakers.

I listened carefully to what others were saying.

During the discussion, I tried to understand why some people

had such opinions.

I tried to familiarise myself with the views of others.

The views of others seemed worthy of consideration. $(M=4.4, S D=0.5$, Cronbach's Alpha $=0.822)$

During the discussion, I started to develop a different view on the issue.

During the discussion, I started thinking about other, equally important, aspects of the issue.

Because of the discussion, I changed my views on the educational treatment. $(M=2.9, S D=0.7$, Cronbach's Alpha $=0.710)$ 
I said what I meant throughout, regardless of other people's reactions. *There were times when I wanted to state the plain truth, but I preferred to be more diplomatic.

${ }^{*}$ I did not feel the atmosphere was relaxed enough for me to express myself sincerely.

*When my opinion differed from that of the majority of participants, I preferred to be quiet.

*Sometimes, I preferred to remain silent, to not ruin the harmony in the group.

$(M=4.0, S D=0.7$, Cronbach's Alpha $=0.768)$

Note: Scales with values $1-5$, where $1=$ totally disagree with the statement and $5=$ totally agree with the statement; to calculate the value of individual indexes, we reverse scored the statements marked with *.

\section{APPENDIX 2}

\section{Deliberative functioning: individual for the group}

Equal participation in discussion

Argumentation

Analyticity

Respect: recognition

Respect: appraisal
* Some speakers arranged for themselves more space for expressing their views than others.

*Some speakers did not talk frequently even if, in my opinion, their views were clear.

* Most of the time, only a few people were speaking.

$(M=3.4, S D=0.9$, Cronbach's Alpha $=0.781)$

The speakers were willing to justify their views.

The speakers' arguments were based on their own experience.

I could say that the discussion was an exchange of

high-quality arguments.

The speakers' arguments were based on expert findings.

$(M=4.1, S D=0.5$, Cronbach's Alpha $=0.732)$

We talked about many interesting topics during the discussion. Many solutions appeared during the discussion.

During the discussion, we also had deeper reflections about the values that serve as guidance in imposing disciplinary measures. $(M=3.8, S D=0.6$, Cronbach's Alpha $=0.608)$

The speakers tried to familiarise themselves with other people's views. *I had a feeling that the speakers were not really interested in other people's opinions.

*Some participants created the impression that they were the only people who were right.

*Some participants tried all means to persuade others that they were right.

Most of the time, the speakers listened carefully to what others had to say.

$(M=4.3, S D=0.5$, Cronbach's Alpha $=0.857)$

The speakers mainly considered what others had to say.

The speakers' contributions were mostly accepted as useful.

The speakers upgraded the previously expressed ideas. 
Readiness for change

Honesty

\section{REFERENCES}

The speakers showed respect for what other people were saying. The speakers perceived each other as competent discussants. $(M=4.2, S D=0.7$, Cronbach's Alpha $=0.865)$

*I have a feeling that the speakers did not change their views about the disciplinary measures during the discussion. During the discussion, the speakers started to develop a different view on the issue.

The discussion helped the participants become familiar with other equally important aspects of the issue.

$(M=3.0, S D=0.6$, Cronbach's Alpha $=0.622)$

I am sure that the speakers mostly said what they really meant. *It seems to me that the speakers were being more diplomatic than speaking the plain truth.

*I have a feeling that the atmosphere was not relaxed enough for the speakers to express themselves sincerely.

*I would say that those speakers whose views differed from the majority preferred to be quiet.

*It seems to me that the speakers did not want to ruin the harmony in the group and sometimes preferred to remain silent.

$(M=4.0, S D=0.6$, Cronbach's Alpha $=0.779)$

Note: Scales with values $1-5$, where $1=$ totally disagree with the statement and $5=$ totally agree with the statement; to calculate the value of individual indexes, we reverse scored the values in the statements marked with *.

Ainsworth, M., Blehar, M., Waters, E., \& Wall, S. (1978). Patterns of attachment: A psychological study of the strange situation. Hillsdale, NJ: Erlbaum.

Bächtiger, A., \& Steenbergen, M. R. (2004). The real world of deliberation. A comparative study of its favorable conditions in legislatures. EUI Working Paper SPS No. 17. Available at http://cadmus.eui.eu/bitstream/ handle/1814/2634/sps2004-17.pdf? sequence $=1$

Bächtiger, A., Shikano, S., Pedrini, S., \& Ryser, M. (2009). Measuring deliberation 2.0: Standards, discourse types, and sequentialization. Available at http://ash.harvard.edu/extension/ash/docs/baechtiger.pdf

Black, L. W., Burkhalter, S., Gastil, J., \& Stromer-Galley, J. (2010). Methods for analyzing and measuring group deliberation. In E. P. Bucy \& R. L. Holbert (Eds.), The sourcebook for political communication research: Methods, measures, and analytic techniques (pp. 323-345). New York, NY: Routledge.

Boccato, G., \& Capozza, D. (2011). Attachment styles and social groups: Review of a decade. Testing, Psychometrics, Methodology in Applied Psychology, 18(1), 19-30.

Bowlby, J. (1991). Attachment and loss. London; New York: Penguin Books.

Cassidy, J., \& Shaver, P. (2008). Handbook of attachment: Theory, research, and clinical applications. New York; London: The Guilford Press. 
DRUŠ. ISTRAŽ. ZAGREB GOD. 27 (2018), BR. 2, STR. 281-303

KUHAR, M., JEZNIK, K. EFFECTS OF GROUP...
Darwall, S. L. (1977). Two kinds of respect. Ethics, 88(1), 36-49. https://doi.org/10.1086/292054

Dillard, K. N. (2013). Envisioning the role of facilitation in public deliberation. Journal of Applied Communication Research, 41(3), 217-235. https://doi.org/10.1080/00909882.2013.826813

Duckitt, J. (2001). A dual process cognitive-motivational theory of ideology and prejudice. Advances in Experimental Social Psychology, 33, 41-113. https://doi.org/10.1016/S0065-2601(01)80004-6

Duckitt, J. (2006). Differential effects of right wing authoritarianism and social dominance orientation on outgroup attitudes and their mediation by threat from competitiveness to outgroups. Personality and Social Psychology Bulletin, 32(5), 684-696. https://doi.org/10.1177/ 0146167205284282

Ein-Dor, T., \& Hirschberger, G. (2016). Rethinking attachment theory: From a theory of relationships to a theory of individual and group survival. Current Directions in Psychological Science, 25(4), 223-227. https://doi.org/10.1177/0963721416650684

Fulwider, J. (2005, September 1-4). Do moderators matter? Answering a jury deliberation challenge to deliberative democracy. Paper presented at the Annual Meeting of the American Political Science Association, Marriott Wardman Park, Omni Shoreham, Washington Hilton, Washington, DC. Available at https://people.ucsc.edu/čhfukurai/Fulwider2005.pdf

Gastil, J., \& Dillard, J. P. (1999). The aims, methods, and effects of deliberative civic education through the national issues forums. Communication Education, 48(3), 179-192. https://doi.org/10.1080/03634529 909379168

Gastil, J., Black, L. W., \& Moscovitz, K. (2008). Ideology, attitude change and deliberation in small face-to-face groups. Political Communication, 25(1), 347-376. https://doi.org/10.1080/10584600701807836

Halvorsen, K. E. (2001). Assessing public participation techniques for comfort, convenience, satisfaction, and deliberation. Environmental Management, 28(2), 179-186. https://doi.org/10.1007/s002670010216

Jost, J. T. (2006). The end of the end of ideology. American Psychologist, 61(7), 651-670. https://doi.org/10.1037/0003-066X.61.7.651

Kahneman, D., \& Tversky, A. (Eds.) (2000). Choices, values, and frames. Cambridge: Cambridge University Press.

Kuhar, M. (2013). Exploring psychological factors influencing deliberation. Interdisciplinary Description of Complex Systems, 11(4), 415-426. https://doi.org/10.7906/indecs.11.4.6

Kuhar, M., \& Jeznik, K. (2017). Effect of deliberative discussion methods on primary school teachers' attitudes towards educational measures [Deliberativno razpravljanje učiteljev o vzgojnih ukrepih v osnovni šoli]. Sodobna pedagogika, 68(1), 32-50.

Landwehr, C. (2014). Facilitating deliberation: The role of impartial intermediaries in deliberative mini-publics. In K. Grönlund, A. Bächtiger, \& M. Setälä (Eds.), Deliberative mini-publics: Involving citizens in the democratic process (pp. 77-92). Colchester: ECPR Press. 
DRUŠ. ISTRAŽ. ZAGREB GOD. 27 (2018), BR. 2 STR. $281-303$

KUHAR, M., JEZNIK, K.: EFFECTS OF GROUP..
Lodge, M., \& Taber, C. S. (2000). Three steps toward a theory of motivated political reasoning. In A. Lupia, M. McCubbins, \& S. Popkin (Eds.), Elements of reason (pp. 183-213). Cambridge: Cambridge Univ. Press. https://doi.org/10.1017/CBO9780511805813.009

Lupia, A. (2002). Deliberation disconnected: What it takes to improve civic competence. Law and Contemporary Problems, 65(3), 133-150. https://doi.org/10.2307/1192406

Mannarini, T. (2011). Public involvement and competent communities: Towards a social psychology of public participation. The Special Issue on Behavioral and Social Science, 1(7), 66-72.

Marcus, G., Neuman, W., \& MacKuen, M. (2000). Affective intelligence and political judgment. Chicago: University of Chicago Press.

Mikulincer, M. (1997). Adult attachment style and information processing: Individual differences in curiosity and cognitive closure. Journal of Personality and Social Psychology, 72(5), 1217-1230. https://doi.org/ 10.1037/0022-3514.72.5.1217

Mikulincer, M., \& Shaver, P. R. (2001). Attachment theory and intergroup bias: Evidence that priming the secure base schema attenuates negative reactions to out-groups. Journal of Personality and Social Psychology, 81(1), 97-115. https://doi.org/10.1037/0022-3514.81.1.97

Morrell, M. E. (2010). Empathy and democracy: Feeling, thinking, and deliberation. The Pennsylvania State University: University Park.

Nabatchi, T. (2007). Deliberative democracy: The effects of participation on political efficacy. (Unpublished doctoral dissertation). Indiana University, Bloomington, IN.

Neblo, M. A., Esterling, K. M., Kennedy, R. P., \& Laze, D. M. J. (2008). Who wants to deliberate, and why. Program on Networked Governance Working Paper PNG No. PNG08-002. Available at https://www. cabridge.org/core/journals/american-political-science-review/article/ div-classtitlewho-wants-to-deliberateand-whydiv/B918F30F1EF25F EE40DFD8313BD83B79

O'Doherty, K. C. (2013). Synthesising the outputs of deliberation: Extracting meaningful results from a public forum. Journal of Public Deliberation, 9(1), Article 8, 4-30.

Petrič, G. (2014). Perceived quality of conversations in online communities: Conceptual framework, scale development, and empirical validation. Cyberpsychology, Behavior, and Social Networking, 17(2), 82-90. https://doi.org/10.1089/cyber.2012.0483

Reykowski, J. (2006). Deliberative democracy and "human nature": An empirical approach. Political Psychology, 27(3), 323-346. https://doi.org/ 10.1111/j.1467-9221.2006.00516.x

Rom, E., \& Mikulincer, M. (2003). Attachment theory and group processes: The association between attachment style and group-related representations, goals, memory, and functioning. Journal of Personality and Social Psychology, 84(6), 1220-1235. https://doi.org/10.1037/ 0022-3514.84.6.1220

Rosenberg, S. (2002). The not so common sense: Differences in how people judge social and political life. Yale University Press: New Haven. https:// doi.org/10.12987/yale/9780300084276.001.0001 
DRUŠ. ISTRAŽ. ZAGREB GOD. 27 (2018), BR. 2, STR. $281-303$

KUHAR, M., JEZNIK, K. EFFECTS OF GROUP...
Rosenberg, S. (2005). The empirical study of deliberative democracy: Setting a research agenda. Acta Politica, 40(2), 212-224. https://doi. org/10.1057/palgrave.ap.5500105

Sager, K. L., \& Gastil, J. (2002). Exploring the psychological foundations of democratic group deliberation: Personality factors, confirming interaction, and democratic decision making. Communication Research Reports, 19(1), 56-66. https://doi.org/10.1080/08824090209384832

Shaver, P. R., \& Mikulincer, M. (2003). The psychodynamics of social judgments: An attachment theory perspective. In J. P. Forgas, K. D. Williams, \& W. von Hippel. (Eds.), Social judgments: Implicit and explicit processes (pp. 85-114). London: Cambridge University Press.

Smith, E. R., Murphy, J., \& Coats, S. (1999). Attachment to groups: Theory and measurement. Journal of Personality and Social Psychology, 77(1), 94-110. https://doi.org/10.1037/0022-3514.77.1.94

Smith, G. (2009). Democratic innovations: Designing institutions for citizen participation. Cambridge: Cambridge University Press. https://doi.org/ 10.1017/CBO9780511609848

Spada, P., \& Vreeland, J. R. (2013). Who moderates the moderators? The effect of non-neutral moderators in deliberative decision making. Journal of Public Deliberation, 9(2), Article 3. Available at http://www. publicdeliberation.net/jpd/vol9/iss2/art3

Steenbergen, M. R., Bächtiger, A., Spörndli, M., \& Steiner, J. (2003). Measuring political deliberation: A discourse quality index. Comparative European Politics, 1(1), 21-48. https://doi.org/10.1057/palgrave.cep. 6110002

Steiner, J. (2012). The foundations of deliberative democracy: Empirical research and normative implications. Cambridge: Cambridge University Press. https://doi.org/10.1017/CBO9781139057486

Thompson, S., \& Hoggett, P. (2001). The emotional dynamics of deliberative democracy. Policy \& Politics, 29(3), 351-364. https://doi.org/ 10.1332/0305573012501396

Weber, C., \& Federico, C. M. (2007). Interpersonal attachment and patterns of ideological belief. Political Psychology, 28(4), 389-416. https:// doi.org/10.1111/j.1467-9221.2007.00579.x

Wojcieszak, M. (2011). Deliberation and attitude polarization: What happens when people with extreme views encounter disagreement. Journal of Communication, 61(4), 596-617. https://doi.org/10.1111/j.14602466.2011.01568.x

Wojcieszak, M. (2012). On strong attitudes and group deliberation: Relationships, structure, changes and effects. Political Psychology, 33(2), 225-242. https://doi.org/10.1111/j.1467-9221.2012.00872.x

Wright, S. (2006). Government-run online discussion fora: Moderation, censorship and the shadow of control. The British Journal of Politics and International Relations, 8(4), 550-568. https://doi.org/10.1111/ j.1467-856x.2006.00247.x 
DRUŠ. ISTRAŽ. ZAGREB GOD. 27 (2018), BR. 2 STR. 281-303

KUHAR, M., JEZNIK, K.: EFFECTS OF GROUP..

\section{Učinci grupnih diskusijskih stilova privrženosti i facilitacije na kvalitetu deliberacije}

Metka KUHAR

Fakultet društvenih znanosti, Ljubliana

Katja JEZNIK

Filozofski fakultet, Ljubljana

U članku smo analizirali kako grupni diskusijski stilovi privrženosti te njihova interakcija s facilitacijom utječu na kvalitetu procesa rasprave (prema deliberativnim kriteriijima, na primjer, jednako sudjelovanje, argumentiranje, poštovanie). Organizirali smo 26 rasprava sa 226 nastavnika iz 13 slovenskih osnovnih škola o obrazovno- disciplinarnim praksama nastavnika. Rasprave, od kojih svaka pojedinačno uključuje 7-12 nastavnika, trajale su po 90 minuta, polovica niih bila je facilitirana sukladno deliberativnim kriteriijima, polovica nefacilitirana. Što je veća diskusiijko grupna anksiozna privrženost, niže su ocjene deliberativnoga funkcioniranja pojedinca i deliberativnoga funkcioniranja grupe. Facilitiranje poboljšava ocjenu deliberativnoga funkcioniranja grupe kod pojedinaca s izraženijom grupnom diskusijsko-anksioznom privrženošću, dok su facilitirane osobe, koje su na višoj razini grupnim diskusiijskim izbjegavanjem privrženošću, procijenile deliberativno funkcioniranje grupe nižim od onih koji nisu facilitirani.

Ključne riječi: deliberacija, grupa za raspravu, facilitacija, stilovi privrženosti, obrazovno-disciplinarne prakse nastavnika

\section{(c) (i) $€$}

Međunarodna licenca / International License:

Creative Commons Attribution-NonCommercial-NoDerivatives 4.0. 